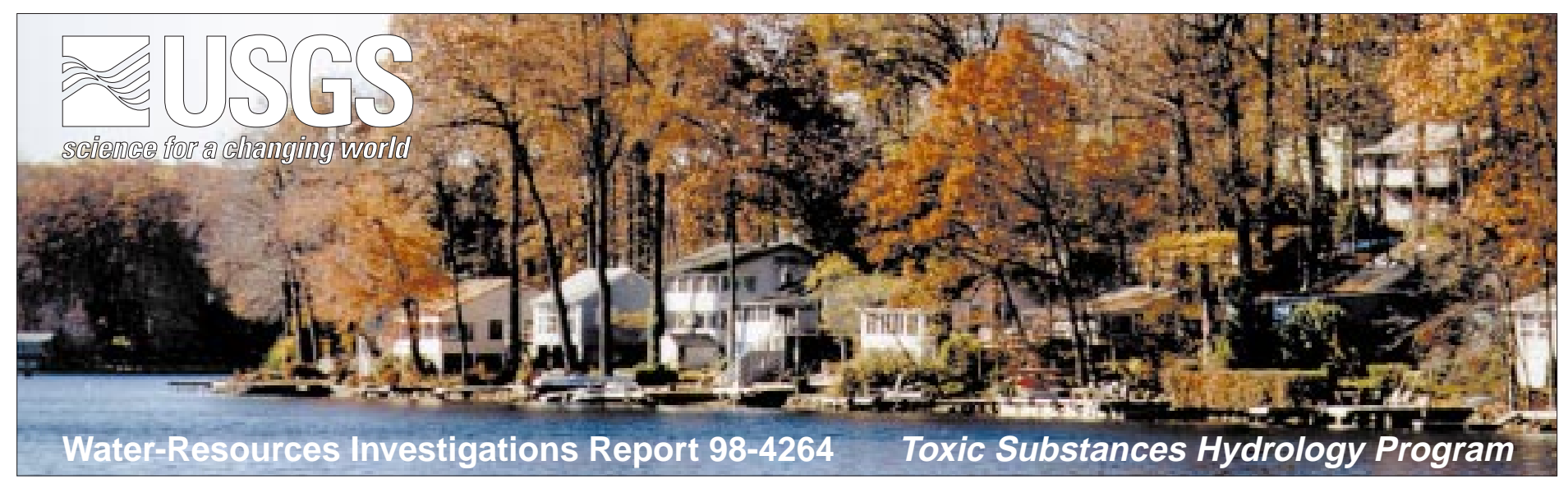

\title{
METHYL TERT-BUTYL ETHER (MTBE) AND OTHER VOLATILE ORGANIC COMPOUNDS IN LAKES IN BYRAM TOWNSHIP, SUSSEX COUNTY, NEW JERSEY, SUMMER 1998
}

\author{
by Arthur L. Baehr and Otto S. Zapecza
}

In cooperation with the Sussex County Health Department

\section{ABSTRACT}

Water samples were collected from four lakes in Byram Township, Sussex County, N.J., in the summer of 1998 as part of an investigation of the occurrence of volatile organic compounds (VOCs) in domestic wells of lakeside communities. Cranberry Lake and Lake Lackawanna are surrounded by densely populated communities where the use of gasoline-powered watercraft is prevalent, and water is supplied by lakeside wells. Forest Lake is surrounded by a densely populated community where the use of gasoline-powered watercraft is prohibited. Stag Pond is privately owned, is situated in a sparsely populated area, and is not navigated by gasoline-powered watercraft. Samples were collected from Cranberry Lake in early summer and again in late summer 1998. Concentrations of the gasoline oxygenate methyl tert-butyl ether (MTBE) ranged from 1.6 to $15.0 \mu \mathrm{g} / \mathrm{L}$ (micrograms per liter) on June 24 and decreased with depth. The depth-related concentration gradient is attributed to density stratification caused by the temperature gradient that is present in the lake during the early summer. MTBE concentrations ranged from 7.4 to $29.0 \mu \mathrm{g} / \mathrm{L}$ on September 8 and were uniform with depth, as was water temperature, indicating that the lake was vertically mixed. On the basis of these concentration profiles, the mass of MTBE in Cranberry Lake was estimated to be 15 kilograms on June 24 and 27 kilograms on September 8. These mass estimates are equal to the amount of MTBE in 52 and 95 gallons, respectively, of gasoline that contains 10 percent MTBE by volume. Concentrations of another gasoline oxygenate, tert-amyl-methyl ether (TAME), ranged from 0.07 to $0.43 \mu \mathrm{g} / \mathrm{L}$ on June 24 and from 0.2 to $0.69 \mu \mathrm{g} / \mathrm{L}$ on September 8 . The highest concentrations of benzene, toluene, ethylbenzene, and xylenes (BTEX) were 0.18, 1.2, 0.18, and $0.97 \mu \mathrm{g} / \mathrm{L}$, respectively, on June 24. All BTEX concentrations in Cranberry Lake on September 8 were less than $0.2 \mu \mathrm{g} / \mathrm{L}$.

Samples were collected from Lake Lackawanna on September 9. Concentrations of MTBE and TAME ranged from 3.7 to $14.0 \mu \mathrm{g} / \mathrm{L}$ and from 0.17 to $0.38 \mu \mathrm{g} / \mathrm{L}$, respectively. Like those in Cranberry Lake the previous day, BTEX concentrations were less than $0.2 \mu \mathrm{g} / \mathrm{L}$, and VOC concentrations and water temperatures were nearly uniform with depth. The mass of MTBE in Lake Lackawanna on September 9 was estimated to be 6 kilograms, which is equal to the amount of MTBE in 21 gallons of gasoline that contains 10 percent MTBE by volume. All VOC concentrations were less than $0.2 \mu \mathrm{g} / \mathrm{L}$ in samples collected from Forest Lake on September 8, 1998, and from Stag Pond on the following day.

Oxygenated gasoline is used in watercraft on lakes across northern New Jersey. Many of these lakes are surrounded by communities similar to those at Cranberry Lake and at Lake Lackawanna, which depend largely on wells for water supply. Therefore, a regional assessment of the occurrence of these compounds in lakes and ground water is needed to determine the effect of the use of oxygenated gasoline on water quality in lakeside environments throughout northern New Jersey.

\section{INTRODUCTION}

Ground water is the major source of water supply for the residents of Cranberry Lake and Lake Lackawanna in Byram Township, Sussex County, N.J. These lakes are man-made (formed with dams), and the combination of maintained water levels and clustered well withdrawal makes lake/well interaction 
likely. Moreover, some residents withdraw water directly from the lakes and treat it before consumption, but the treatment may not be effective for MTBE. Because MTBE is a possible human carcinogen (U.S. Environmental Protection Agency, 1997), the presence of MTBE in the lakes could threaten the quality of the local water supply.

Byram Township is in the southeastern corner of Sussex County in the New Jersey Highlands (New England physiographic province) in northwestern New Jersey, about 50 miles west of New York City. The Highlands province is a northeast-southwest-trending system of folded and faulted Precambrian and Paleozoic rocks that form a terrain characterized by forested, hilly uplands and narrow valleys. The bedrock underlying Byram Township consists of a complex suite of metamorphic and igneous crystalline rocks composed predominantly of hornblende granite, syenite, and gneiss (Volkert and others, 1989). The Township lies just north of the Pleistocene terminal moraine of the Wisconsin glacier. Erosion and deposition associated with the glaciation explain, in part, the presence of many lakes throughout the Highlands and Valley and Ridge provinces of northwestern New Jersey (fig. 1).

Byram Township, referred to as "the Township of Lakes" (Byram Township Environmental Commission, 1994), contains more than two dozen lakes and ponds. Communities surrounding the larger man-made lakes, such as Cranberry Lake, Lake Lackawanna, and Forest Lake, are densely populated because of their picturesque surroundings, bathing beaches, and facilities for boating and water sports. Cranberry Lake was created in the

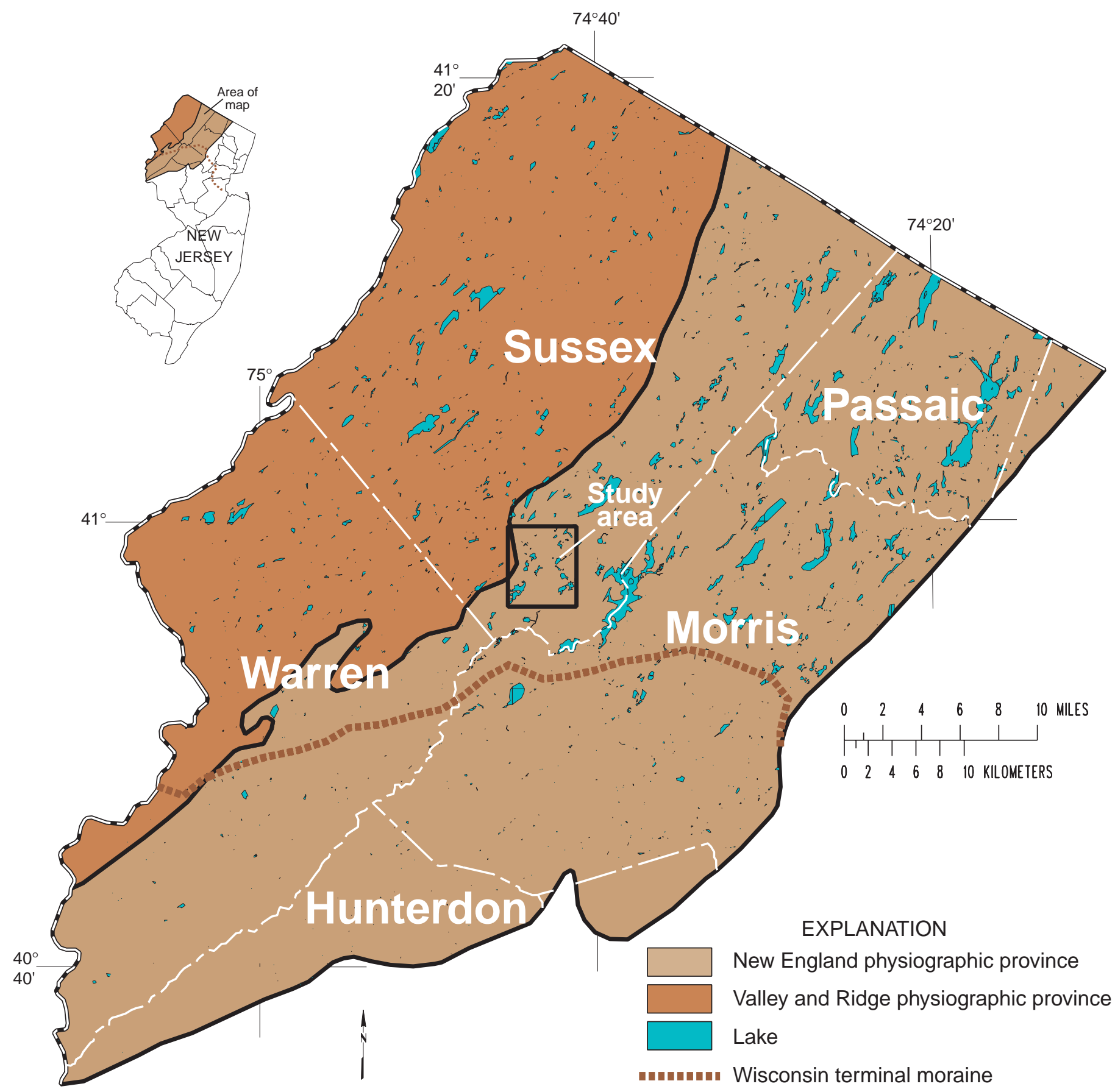

Figure 1. Location of study area, lakes, and physiographic provinces, northwestern New Jersey. 
1830's. Ground water from fractured crystalline rock is the major source of water supply for approximately 500 residences surrounding Cranberry Lake. About 160 of these residences are served by four small water companies; most of the other residences have individual domestic wells. Lake Lackawanna was created in 1910. Ground water from fractured crystalline rock on its western shore and from stratified glacial drift on its eastern shore is the major source of water for approximately 300 residences surrounding Lake Lackawanna. No water companies serve the Lake Lackawanna community and, therefore, all ground water withdrawn is from domestic wells. Some residences in the Cranberry Lake and Lake Lackawanna communities use water taken directly from the lake after some form of in-house treatment. Forest Lake was created in the 1950's. Ground water is the source of water supply for approximately 400 residences surrounding Forest Lake, which are served by a water company that operates two wells. One well taps stratified glacial drift and the other taps fractured crystalline rock. Stag Pond is a privately owned lake in a sparsely populated area.

The U.S. Geological Survey (USGS) became involved in an investigation, coordinated by the Sussex County Health Department, of methyl tert-butyl ether (MTBE) contamination of water from wells in a neighborhood of Cranberry Lake. As part of this investigation, water samples collected from Cranberry Lake on June 24, 1998, were analyzed for volatile organic compounds (VOCs) to determine whether lake-water quality is related to the ground-water contamination. Concentrations of MTBE in Cranberry Lake were elevated, but lower than concentrations observed in some wells. Additional samples were collected from Cranberry Lake on September 8, 1998. Lake Lackawanna was sampled on September 9, 1998, to determine concentrations of VOCs in another lake in the area in which the use of gasoline-powered watercraft is prevalent. Forest Lake was sampled on September 8, 1998, to determine concentrations of VOCs in a lake surrounded by a densely populated community where gasoline-powered watercraft are prohibited. Stag Pond was sampled on September 9, 1998, to determine VOC concentrations in a lake with minimal exposure to effects of human activities.

\section{USE OF MTBE AND OTHER ETHER OXYGENATES IN GASOLINE}

MTBE has been added to gasoline in small quantities since the late 1970's as an octane booster. MTBE use is now (1998) substantially greater because the compound has been blended in gasoline in urban areas throughout the country since the winter of 1992, when requirements associated with amendments made to the Federal Clean Air Act in 1990 went into effect. For example, the Clean Air Act requires that gasoline sold in carbon monoxide nonattainment areas contain at least 2.7 percent oxygen. This oxygen content is achieved by adding 14.8 percent MTBE by volume to gasoline. MTBE is by far the most widely used oxygenate. Tert-amyl-methyl ether (TAME), a less commonly used gasoline oxygenate, also can be associated with MTBE as a by-product. Another ether oxygenate measured in this study is ethyl tert-butyl ether (ETBE).

MTBE is more soluble, less volatile, and less reactive than other constituents of gasoline such as benzene, toluene, ethylbenzene, and xylenes (BTEX)(Zogorski and others, 1997); therefore, when oxygenated gasoline is spilled, MTBE typically is the dominant gasoline constituent of the contaminated water. The use of MTBE in gasoline across the country is a topic of considerable debate (Andrews, 1998) as scientists and regulators evaluate the benefits of improved air quality in relation to the widespread occurrence of MTBE in ground and surface water.

\section{SAMPLING SITES AND PROCEDURES}

Cranberry Lake is about 187 acres in size. A bathymetric map produced in 1992 shows that the deepest parts of the lake are about $16 \mathrm{ft}$ (feet) deep and that the average depth is about $7 \mathrm{ft}$ (Coastal Environmental Services, 1992). On June 24, 1998, samples were collected at a depth of $3 \mathrm{ft}$ below the lake surface at 12 locations (fig. 2). Depth measurements at these locations agreed closely with the 1992 bathymetric map. At three locations, where the lake is relatively deep, a second sample was collected at a depth of $10 \mathrm{ft}$. On September 9, 1998, samples were collected near 9 of the 12 locations at which samples had been collected on June 24 to assess conditions at the end of the summer. At the three sites where two samples had been collected previously, samples were collected at depths of 3, 6, and $10 \mathrm{ft}$. Depth measurements at the sampling sites indicate that the lake surface was about $1.2 \mathrm{ft}$ lower than on June 24, as a result of the dry summer. Lake Lackawanna is approximately 109 acres in size. A bathymetric map (Perrone, 1989) shows that its maximum depth is about $10 \mathrm{ft}$ and its average depth is about $4 \mathrm{ft}$. On September 9, 1998, samples were collected at a depth of $3 \mathrm{ft}$ below lake surface at five locations (fig. 2). At two of these locations, a second sample was collected $5 \mathrm{ft}$ below the lake surface. Lubbers Run, the stream that discharges to Lake Lackawanna, was sampled once near the lake inlet.

Forest Lake is about 44 acres in size. On September 8, 1998, its maximum and average depths were estimated to be 15 and $11 \mathrm{ft}$, respectively. On September 8, 1998, samples were collected from Forest Lake at a depth of $3 \mathrm{ft}$ below the lake surface at four locations (fig. 2). At two of these locations, a second sample was collected $10 \mathrm{ft}$ below the lake surface. Stag Pond is a natural lake with an area of about 33 acres. On September 9, 1998, its maximum and average depths were estimated to be 25 and $16 \mathrm{ft}$, respectively. On September 9, 1998, samples were collected from Stag Pond at a depth of $3 \mathrm{ft}$ below the lake surface at two locations (fig. 2).

Sites were accessed with a boat equipped with an electric motor. A length of 0.25-inch outside-diameter Teflon tubing was strapped onto a sampling staff and lowered to the desired depth. Back pressure was maintained while the sampling line was being lowered to prevent water above the desired sampling depth from entering the tubing before sampling. No sheens due to spilled oil or gas were observed at any time on any of the lakes. After the sampling line was purged, samples were withdrawn with a peristaltic pump and collected in $40-\mathrm{mL}$ (milliliter) VOC vials. A short length of flexible silicon tubing was fitted around the pump head and spliced into the Teflon sampling line by pushing the Teflon line snugly into the flexible tubing. Because new tubing was used at each sampling site or depth, no decontamination procedures were required. Equipment blanks were collected by sampling VOC-free water with the same apparatus using a 10-ft length of Teflon tubing. At each site, temperature was measured 


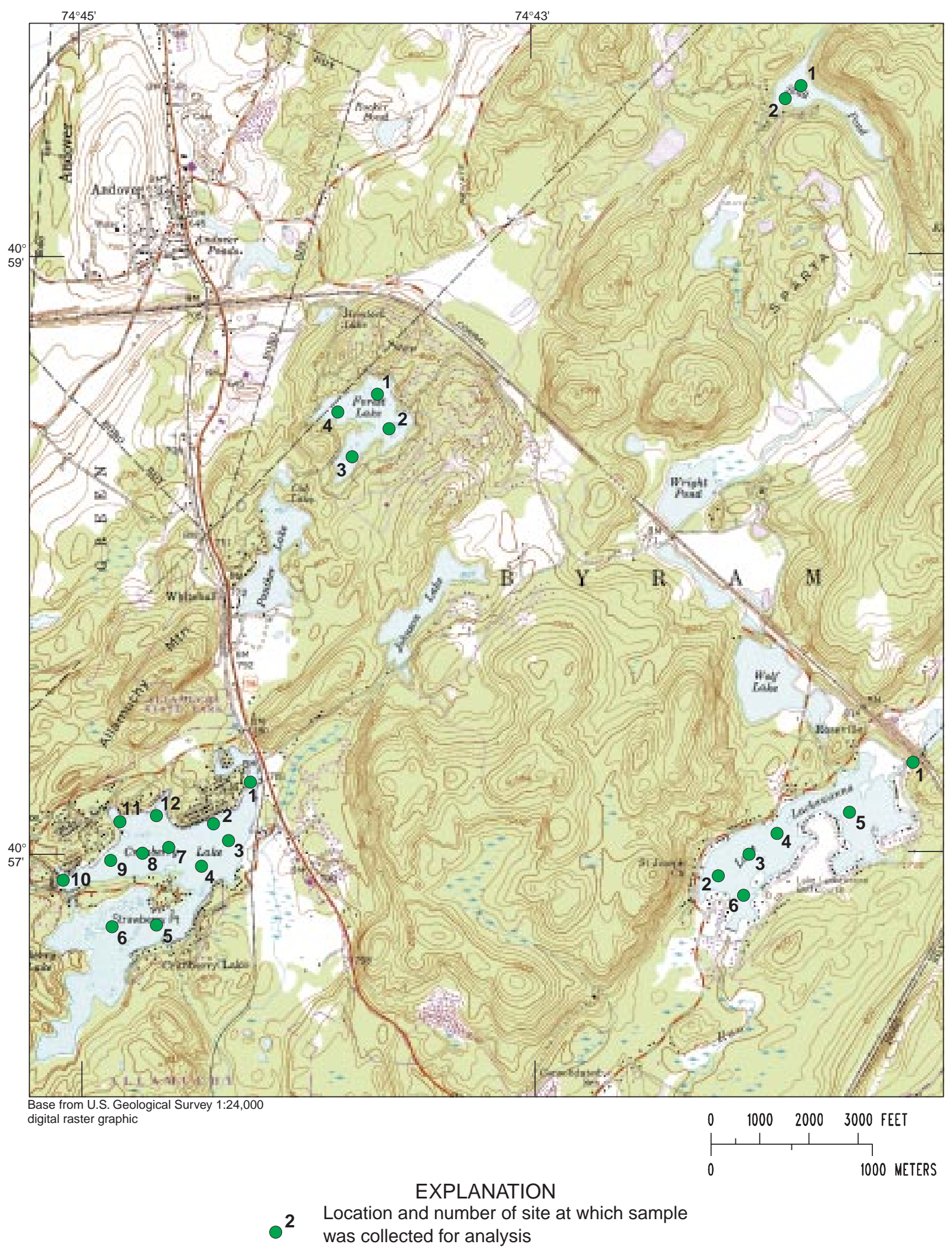

Figure 2. Lake sampling sites, Sussex County, New Jersey. 
as a function of depth in the lake.

The peristaltic pump applies a pressure to the sample stream that is less than atmospheric, a condition that theoretically could result in VOC mass loss when the sample is transferred to the vial. In lake sampling, however, water is lifted only about $1 \mathrm{ft}$ from the lake surface to near the bottom of the boat, where the vials are filled. This lift corresponds to a pressure differential of less than 3 percent of atmospheric pressure (1 standard atmosphere is equal to 406.38 inches of water); therefore, any VOC loss is negligible.

Samples were preserved with 1:1 hydrochloric acid, immediately stored on ice, and sent overnight to the USGS National Water-Quality Laboratory in Arvada, Colo.

Concentrations of VOCs were determined by gas

chromatography-mass spectrometry (Connor and others, 1998). In addition to BTEX and the ether gasoline oxygenates MTBE, TAME, and ETBE, the analysis included the following VOCs:

\begin{tabular}{l|l}
$\begin{array}{l}\text { bromodichloromethane } \\
\text { bromoform }\end{array}$ & $\begin{array}{l}\text { 1,1-dichloroethene } \\
\text { cis-1,2-dichloroethene } \\
\text { carbon tetrachloride } \\
\text { chlorobenzene }\end{array}$ \\
$\begin{array}{l}\text { trans-1,2-dichloroethene } \\
\text { 1,2-dichloropropane } \\
\text { 1,2-dichlorobenzene }\end{array}$ & methylene chloride \\
1,3-dichlorobenzene & styrene \\
1,4-dichlorobenzene & tetrachloroethene \\
dibromochloromethane & 1,1,1-trichloroethane \\
dichlorodifluoromethane & trichloroethene \\
1,1-dichloroethane & trichlorofluoromethane \\
1,2-dichloroethane & vinyl chloride
\end{tabular}

\section{CONCENTRATIONS AND MASS ESTIMATES}

Concentrations of VOCs and other data obtained during the June 24 and September 8 synoptic sampling of Cranberry Lake are listed in tables $1 \mathrm{a}$ and $1 \mathrm{~b}$, respectively. Data obtained from Lake Lackawanna on September 9 are summarized in table 2. The only VOCs detected in any of the samples were MTBE, TAME, and BTEX; MTBE and TAME were detected in every sample from Cranberry Lake and Lake Lackawanna. No VOC concentration in any sample from Forest Lake or Stag Pond exceeded $0.2 \mu \mathrm{g} / \mathrm{L}$.

The concentrations of MTBE in samples collected $3 \mathrm{ft}$ below the surface in Cranberry Lake on June 24 ranged from 10.1 to $15.0 \mu \mathrm{g} / \mathrm{L}$; therefore, MTBE was evenly distributed across the upper part of the lake (table 1a). MTBE concentrations were lowest $(1.6,3.8$, and $4.3 \mu \mathrm{g} / \mathrm{L})$ in samples from $10 \mathrm{ft}$ below the surface. The difference in concentration with depth is attributed to density stratification caused by the vertical temperature gradient that is present in Cranberry Lake in the early summer. Temperature profiles at the three sites at which samples were collected at multiple depths are shown in figure 3 .

TAME concentrations were much lower than MTBE concentrations; however, spatial trends for MTBE and TAME concentrations were similar, as evidenced by their high correlation $\left(r^{2}=0.979\right)$. BTEX concentrations generally are correlated with MTBE and TAME concentrations; however, BTEX was not detected in all samples.

These concentration data do not allow for an accurate

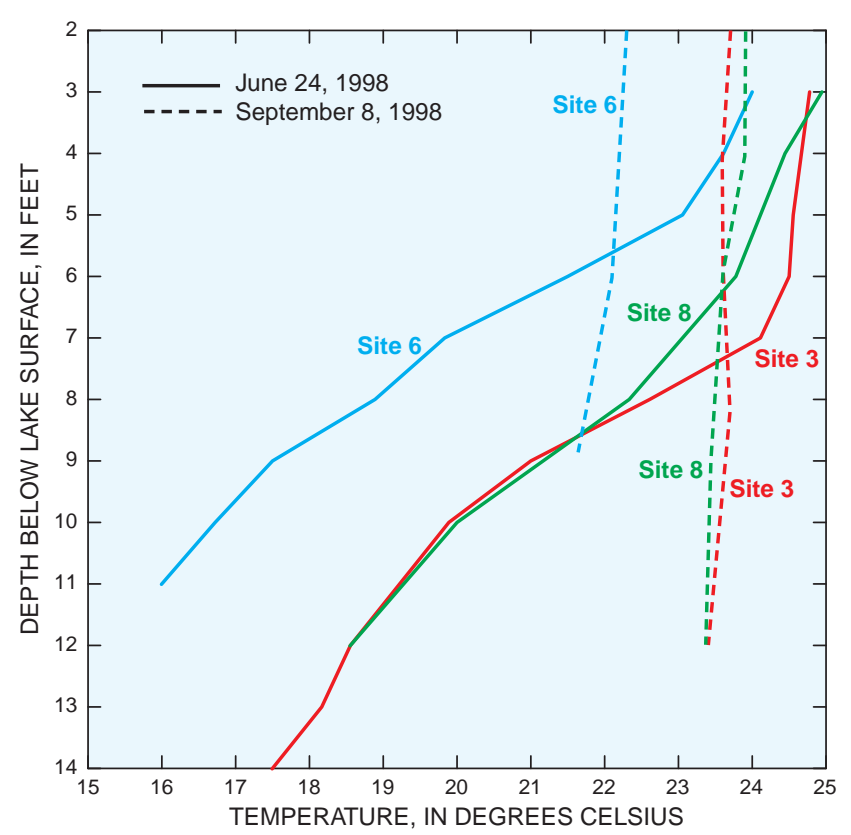

Figure 3. Temperature as a function of depth at sites at which samples were collected at multiple depths, Cranberry Lake, Sussex County, New Jersey, summer 1998.

estimate of the VOC mass in Cranberry Lake because the functional dependence of concentration on depth cannot be determined with data from only two sampling depths.

Nevertheless, VOC mass estimates, although approximate, can be used to scale the source strength and for comparison with estimates of VOC mass at the end of the summer. Estimates of MTBE and TAME mass in Cranberry Lake on June 24 are 15 and $0.45 \mathrm{~kg}$ (kilograms), respectively. Mass estimates were obtained by numerically integrating concentration over the volume of the lake. Concentrations were assumed to be uniform through the upper $3 \mathrm{ft}$ of the lake and to decline exponentially beneath $3 \mathrm{ft}$ to the lake bottom. Values of parameters that define the exponential decline in concentration with depth were obtained by using average concentrations at the 3 - and $10-\mathrm{ft}$ depths. The mass of BTEX could not be estimated because most BTEX concentrations at the 10-ft depth were reported as $<0.2 \mu \mathrm{g} / \mathrm{L}$. The estimated MTBE mass of $15 \mathrm{~kg}$ in Cranberry Lake on June 24 is equivalent to 52 gal (gallons) of a gasoline that is 10 percent MTBE by volume, an MTBE content representative of gasoline used in the region. If the density of gasoline is assumed to be 0.75 grams per cubic centimeter, 10 percent MTBE by volume corresponds to $281.6 \mathrm{~g}$ (grams) of MTBE per gallon of gasoline.

MTBE concentrations in samples collected from Cranberry Lake on September 8 ranged from 7.4 to $29.0 \mu \mathrm{g} / \mathrm{L}$ (table 1b). At the three sites where three samples were collected at different depths, MTBE concentrations and water temperature were nearly uniform (fig. 3), indicating that the lake was vertically mixed. Concentrations were lowest in samples from site 6, which is at the shallow end of Cranberry Lake nearest the inlet stream (fig. 2). TAME concentrations ranged from 0.19 to $0.69 \mu \mathrm{g} / \mathrm{L}$ and are significantly correlated $\left(r^{2}=0.829\right)$ with MTBE concentrations. BTEX concentrations were less than $0.2 \mu \mathrm{g} / \mathrm{L}$ in all samples, in contrast to the higher MTBE and 
Table 1a. Concentrations of volatile organic compounds in samples from Cranberry Lake, Sussex County, N.J., June 24, 1998

[Concentrations are in micrograms per liter; sample depth in feet below lake surface; <, less than]

\begin{tabular}{|c|c|c|c|c|c|c|c|c|}
\hline \multirow[b]{2}{*}{$\begin{array}{c}\text { Site } \\
\text { number }\end{array}$} & \multirow[b]{2}{*}{ Site name } & \multirow{2}{*}{$\begin{array}{c}\text { Sample } \\
\text { depth } \\
\text { (feet) }\end{array}$} & \multicolumn{6}{|c|}{ Concentration } \\
\hline & & & MTBE & TAME & Benzene & Toluene & $\begin{array}{c}\text { Ethyl- } \\
\text { benzene }\end{array}$ & Xylenes \\
\hline 1 & $1306 \mathrm{~N}$ & 3 & 13.6 & .38 & .12 & .65 & 0.12 & .65 \\
\hline 2 & 898WNW & 3 & 13.2 & .37 & $<.20$ & $<.20$ & $<.20$ & $<.20$ \\
\hline 3 & $306 \mathrm{~W}$ & 3 & 13.9 & .37 & $<.20$ & .21 & $<.20$ & .12 \\
\hline 3 & $306 W$ & 10 & 4.3 & .16 & $<.20$ & .20 & $<.20$ & $<.20$ \\
\hline 4 & 694SW & 3 & 12.5 & .36 & $<.20$ & $<.20$ & $<.20$ & $<.20$ \\
\hline 5 & 2041SW & 3 & 12.2 & .32 & $<.20$ & $<.20$ & $<.20$ & $<.20$ \\
\hline 6 & 2449SW & 3 & 10.1 & .26 & $<.20$ & .15 & $<.20$ & $<.20$ \\
\hline 6 & 2449SW & 10 & 1.6 & .07 & $<.20$ & $<.20$ & $<.20$ & $<.20$ \\
\hline 7 & $1061 W$ & 3 & 11.0 & .38 & .11 & .39 & $<.20$ & .51 \\
\hline 8 & 1633W & 3 & 14.0 & .40 & .10 & .28 & $<.20$ & .41 \\
\hline 8 & $1633 W$ & 10 & 3.8 & .15 & $<.20$ & $<.20$ & $<.20$ & $<.20$ \\
\hline 9 & 2245WSW & 3 & 13.2 & .41 & $<.20$ & .17 & $<.20$ & .25 \\
\hline 10 & 3061WSW & 3 & 14.2 & .40 & $<.20$ & $<.20$ & $<.20$ & $<.20$ \\
\hline 11 & 2000WNW & 3 & 14.2 & .40 & $<.20$ & $<.20$ & $<.20$ & .17 \\
\hline 12 & 1388NW & 3 & 15.0 & .43 & .18 & 1.20 & .18 & .97 \\
\hline & Blank & & $<.20$ & $<.20$ & $<.20$ & $<.20$ & $<.20$ & $<.20$ \\
\hline
\end{tabular}

Table 1b. Concentrations of volatile organic compounds in samples from Cranberry Lake, Sussex County, N.J., September 8, 1998

[Concentrations are in micrograms per liter; sample depth in feet below lake surface; <, less than; (rep.), replicate sample]

\begin{tabular}{|c|c|c|c|c|c|c|c|c|}
\hline \multirow[b]{2}{*}{$\begin{array}{c}\text { Site } \\
\text { number }\end{array}$} & \multirow[b]{2}{*}{ Site name } & \multirow{2}{*}{$\begin{array}{c}\text { Sample } \\
\text { depth } \\
\text { (feet) }\end{array}$} & \multicolumn{6}{|c|}{ Concentration } \\
\hline & & & MTBE & TAME & Benzene & Toluene & $\begin{array}{c}\text { Ethyl- } \\
\text { benzene }\end{array}$ & Xylenes \\
\hline 1 & $1306 \mathrm{~N}$ & 3 & 27.3 & .57 & $<.40$ & $<.40$ & $<.40$ & $<.40$ \\
\hline 3 & $306 W$ & 3 & 22.0 & .65 & $<.20$ & .14 & $<.20$ & $<.20$ \\
\hline 3 & $306 W$ & 6 & 21.9 & .69 & $<.20$ & .20 & $<.20$ & $<.20$ \\
\hline 3 & $306 W$ & 10 & 28.1 & .59 & $<.40$ & $<.40$ & $<.40$ & $<.40$ \\
\hline 3 & $306 W$ & 10 (rep.) & 25.8 & .63 & $<.20$ & $<.20$ & $<.20$ & $<.20$ \\
\hline 4 & 694SW & 3 & 29.0 & .60 & $<.20$ & $<.20$ & $<.20$ & $<.20$ \\
\hline 6 & 2449SW & 3 & 8.0 & .19 & $<.20$ & $<.20$ & $<.20$ & $<.20$ \\
\hline 6 & 2449SW & 6 & 8.0 & .20 & $<.20$ & $<.20$ & $<.20$ & $<.20$ \\
\hline 6 & 2449SW & 9 & 7.4 & .19 & $<.20$ & $<.20$ & $<.20$ & $<.20$ \\
\hline 7 & $1061 W$ & 3 & 19.8 & .62 & $<.20$ & $<.20$ & $<.20$ & $<.20$ \\
\hline 8 & 1633W & 3 & 20.1 & .63 & $<.20$ & $<.20$ & $<.20$ & $<.20$ \\
\hline 8 & 1633W & 6 & 20.6 & .63 & $<.20$ & $<.20$ & $<.20$ & $<.20$ \\
\hline 8 & 1633W & 10 & 20.5 & .62 & $<.20$ & $<.20$ & $<.20$ & $<.20$ \\
\hline 9 & 2245WSW & 3 & 20.8 & .65 & $<.20$ & $<.20$ & $<.20$ & $<.20$ \\
\hline 10 & 3061WSW & 3 & 18.3 & .51 & $<.20$ & $<.20$ & $<.20$ & $<.20$ \\
\hline \multirow[t]{2}{*}{12} & 1388NW & 3 & 23.8 & .50 & $<.40$ & $<.40$ & $<.40$ & $<.40$ \\
\hline & Blank & & $<.20$ & $<.20$ & $<.20$ & $<.20$ & $<.20$ & $<.20$ \\
\hline
\end{tabular}


Table 2. Concentrations of volatile organic compounds in samples from Lake Lackawanna, Sussex County, N.J., September 9, 1998

[Concentrations are in micrograms per liter; sample depth in feet below lake surface; <, less than; (rep.), replicate sample]

\begin{tabular}{|c|c|c|c|c|c|c|c|c|}
\hline \multirow[b]{2}{*}{$\begin{array}{c}\text { Site } \\
\text { number }\end{array}$} & \multirow[b]{2}{*}{ Site name } & \multirow{2}{*}{$\begin{array}{c}\text { Sample } \\
\text { depth } \\
\text { (feet) }\end{array}$} & \multicolumn{6}{|c|}{ Concentration } \\
\hline & & & MTBE & TAME & Benzene & Toluene & $\begin{array}{c}\text { Ethyl- } \\
\text { benzene }\end{array}$ & Xylenes \\
\hline 1 & Lubbers Run & 1.5 & $<.20$ & $<.20$ & $<.20$ & $<.20$ & $<.20$ & $<.20$ \\
\hline 2 & $1085 \mathrm{NE}$ & 3 & 12.0 & .27 & $<.20$ & $<.20$ & $<.20$ & $<.20$ \\
\hline 3 & $1564 N$ & 3 & 14.0 & .27 & $<.20$ & $<.20$ & $<.20$ & $<.20$ \\
\hline 3 & $1564 N$ & 5 & 14.0 & .28 & $<.20$ & $<.20$ & $<.20$ & $<.20$ \\
\hline 4 & 2150NE & 3 & 11.0 & .38 & $<.20$ & $<.20$ & $<.20$ & $<.20$ \\
\hline 4 & 2150NE & 3(rep.) & 12.0 & .37 & $<.20$ & $<.20$ & $<.20$ & $<.20$ \\
\hline 5 & 3237NE & 3 & 3.7 & .17 & $<.20$ & $<.20$ & $<.20$ & $<.20$ \\
\hline 6 & $751 \mathrm{NE}$ & 3 & 12.0 & .25 & $<.20$ & $<.20$ & $<.20$ & $<.20$ \\
\hline \multirow[t]{2}{*}{6} & $751 \mathrm{NE}$ & 5 & 12.0 & .25 & $<.20$ & $<.20$ & $<.20$ & $<.20$ \\
\hline & Blank & & $<.20$ & $<.20$ & $<.20$ & $<.20$ & $<.20$ & $<.20$ \\
\hline
\end{tabular}

TAME concentrations observed on September 8 than on June 24. These observations are not inconsistent, however, because MTBE and TAME concentrations increase during the summer as a result of the increased operation of gasoline-powered watercraft, whereas summer temperatures increase BTEX volatilization and degradation rates more than those of MTBE and TAME. Also, BTEX concentrations typically were less than $1 \mu \mathrm{g} / \mathrm{L}$ on June 24 , and these compounds were further diluted by mixing by September 8. Mass estimates for MTBE and TAME in Cranberry Lake on September 8 are 27 and $0.70 \mathrm{~kg}$, respectively. These estimates were obtained by numerically integrating concentration over the volume of the lake with the assumption that concentrations are constant with depth. The mass of MTBE in Cranberry Lake on September 8 is equivalent to $95 \mathrm{gal}$ of a gasoline that is 10 percent MTBE by volume (281.6 $\mathrm{g}$ of MTBE per gallon of gasoline). MTBE and TAME mass estimates for Cranberry Lake on September 8 are approximately 1.8 and 1.6 times those on June 24, as a result of the net accumulation of these ether oxygenates in the lake during the summer season when use of gasoline-powered watercraft is at its peak.

MTBE concentrations in samples collected from Lake Lackawanna on September 9 ranged from 3.7 to $14.0 \mu \mathrm{g} / \mathrm{L}$ (table 2 ). The concentration was lowest at site 5 , which is near the Lubbers Run inlet, in the shallowest part of the lake. Concentrations of all VOCs, including MTBE and TAME, in a sample from Lubbers Run just upstream from Lake Lackawanna were less than $0.2 \mu \mathrm{g} / \mathrm{L}$. At the two sites where two samples were collected at different depths, MTBE concentrations were unrelated to depth, and water temperature was nearly constant with depth, indicating that the lake was vertically mixed. BTEX concentrations in all samples were less than $0.2 \mu \mathrm{g} / \mathrm{L}$. Mass estimates for MTBE and TAME in Lake Lackawanna on September 9 are 6.0 and $0.15 \mathrm{~kg}$, respectively. These mass estimates were obtained by numerically integrating concentration over the volume of the lake with the assumption that concentrations were constant with depth. The mass of MTBE in Lake Lackawanna on September 9 is equivalent to 21 gal of a gasoline that is 10 percent MTBE by volume.

\section{SIGNIFICANCE OF FINDINGS}

MTBE concentrations in Cranberry Lake and Lake Lackawanna are of immediate concern. The State of New Jersey has set a maximum contaminant level (MCL) of $70 \mu \mathrm{g} / \mathrm{L}$ for MTBE (N.J. Department of Environmental Protection, 1997). This MCL is under review because other regulatory agencies have recently set even more stringent concentration guidelines. The U.S. Environmental Protection Agency has classified MTBE as a possible human carcinogen and has issued a drinking-water advisory for aesthetic concerns of 20 to $40 \mu \mathrm{g} / \mathrm{L}$ (U.S.

Environmental Protection Agency, 1997). The State of California has established a draft secondary MCL for MTBE based on taste and odor, of $5 \mu \mathrm{g} / \mathrm{L}$, and a draft primary MCL for MTBE, of 14 $\mu \mathrm{g} / \mathrm{L}$ (California Department of Health Services, 1998). The State of Maine has set a drinking-water standard of $35 \mu \mathrm{g} / \mathrm{L}$ for MTBE (Smith and Kemp, 1998).

The major benefit derived from oxygenated gasoline is in its use in automobiles; however, because gasoline formulation is not specific to use, oxygenated gasoline is used in watercraft across northern New Jersey. Fuel is routinely introduced to water simply by operating gasoline-powered watercraft, which have been associated with MTBE occurrence in lakes in Nevada and California (Boughton and Lico, 1998; Reuter and others, 1998). Spills associated with the handling of gasoline for refueling watercraft can increase the possibility that the underlying aquifer will be contaminated. The occurrence of MTBE and other VOCs in wells surrounding Cranberry Lake and Lake Lackawanna needs to be determined to evaluate the quality of the local water supply. Many lakes in northern New Jersey are surrounded by communities similar to those of Cranberry Lake and Lake Lackawanna, which depend largely on wells for water supply. Therefore, a regional assessment of the occurrence of these compounds in lakes and ground water is needed to determine the effect of the use of oxygenated gasoline on water quality in lakeside environments throughout northern New Jersey. 


\section{ACKNOWLEDGMENTS}

The authors appreciate the leadership and assistance of Steven Stiansen of the Sussex County Health Department. Joan Skillin and Marcia Chirico, also of the Sussex County Health Department, helped with sampling. Steven Glasson of the Cranberry Lake Environmental Commission coordinated the use of boats and navigated during sampling trips. Donald Rice of the USGS interpreted bathymetric maps to obtain lake-volume and VOC-mass estimates, and Emmanuel Charles of the USGS coordinated sample handling and entry of analysis results into the USGS data base.

\section{REFERENCES CITED}

Andrews, C., 1998, MTBE-A long-term threat to ground water quality: Ground Water, v. 36, no. 5, p. 705-706.

Boughton, C.J., and Lico, M.S., 1998, Volatile organic compounds in Lake Tahoe, Nevada, and California, JulySeptember 1997: U.S. Geological Survey Fact Sheet FS-055-98, 2 p.

Byram Township Environmental Commission, 1994, Natural resources inventory of Byram Township, N.J., June 1994, $173 \mathrm{p}$.

California Department of Health Services, 1998, Drinking-water standards for MTBE: accessed October 19, 1998, at URL http://www.dhs.cahwnet.gov/org/ps/ddwem/chemicals/ MTBE/mtbestand. html Coastal Environmental Services Inc., 1992, Cranberry Lake diagnostic feasibility study: Princeton, N.J., April 2, 1992, 251 p.

Connor, B.F., Rose, D.L., Noriega, M.C., Murtagh, L.K., and Abney, S.R., 1998, Methods of analysis by the U.S.

Geological Survey National Water Quality LaboratoryDetermination of 86 volatile organic compounds in water by gas chromatography/mass spectrometry, including detections less than reporting limits: U.S. Geological Survey Open-File Report 97-829, 78 p.
New Jersey Department of Environmental Protection, 1997, Federal and N.J. State primary and secondary drinking-water standards as of November 1996: Water Supply Element, New Jersey Department of Environmental Protection, Bureau of Safe Drinking Water, Trenton, N.J., 1 p.

Perrone, Steven, 1989, New Jersey lake survey map guide: Pennsauken, N.J., Comtech Lithographics, Inc., 116 p.

Reuter, J.E., Allen, B.C., Richards, R.C., Pankow, J.F., Goldman, C.R., Scholl, R.L., and Seyfried, J.S., 1998, Concentrations, sources, and fate of the gasoline oxygenate methyl tert-butyl ether (MTBE) in a multiple-use lake: Environmental Science and Technology, v. 32, no. 23, p. 3666-3672.

Smith, A.E., and Kemp, P.A., 1998, Maximum Contaminant Level for methyl tertiary-butyl ether (MTBE): Technical support document, Bureau of Health, Maine Department of Human Services, Augusta, Maine, February 1, 1998.

U.S. Environmental Protection Agency, 1997, Drinking-water advisory: Consumer acceptability advice and health effects analysis on methyl tertiary-butyl ether (MTBE): U.S. Environmental Protection Agency, Office of Water, EPA-822-F-97-008.

Volkert, R.A., Monteverde, D.H., and Drake, A.A., Jr., 1989, Bedrock geologic map of the Stanhope quadrangle, Sussex and Morris Counties, New Jersey: U.S. Geological Survey Geologic Quadrangle Map GQ-16, 1 sheet, scale 1:24,000.

Zogorski, J.S., Morduchowitz, A., Baehr, A.L., Bauman, B.J., Conrad, D.L., Drew, R.T., Korte, N.E., Lapham, W.W., Pankow, J.F., and Washington, E.R., 1997, Fuel oxygenates and water quality, in Interagency assessment of oxygenated fuels: National Science and Technology Council, June 1997, chap. 2, p. 2-1 to 2-80.

\section{Additional information can be obtained from:} District Chief

U.S. Geological Survey

810 Bear Tavern Road, Suite 206

West Trenton, NJ 08628

This report can be accessed on the Internet at the following website: <http://nj.usgs.gov/>

Information on the Toxics Substances Hydrology Program is available at the following website: $<$ http://toxics.usgs.gov/toxics/> 